\title{
Effects of pre-chilling potassium nitrate and post-chilling hydrogen cyanamide application on carbohydrate and water dynamics of 'Housui' Japanese pear spur buds during dormancy under mild winter conditions
}

${ }^{1}$ Humberto Mitio Horikoshi, ${ }^{2}$ Yoshihiko Sekozawa, ${ }^{3}$ Sumiko Sugaya

${ }^{1}$ Graduate School of Life and Environmental Sciences, University of Tsukuba, Tsukuba 305-8572, Japan,

humberto_hmh@hotmail.com

${ }^{2}$ Faculty of Life and Environmental Sciences, University of Tsukuba, Tsukuba 305-8572, Japan,

sekozawa.yoshihik.ga@u.tsukuba.ac.jp

${ }^{3}$ Faculty of Life and Environmental Sciences, University of Tsukuba, Tsukuba 305-8572, Japan,

sugaya.sumiko.fw@u.tsukuba.ac.jp

ISSN 2448-0479

Abstract - Japanese pear (Pyrus pyrifolia Nakai) trees were treated with potassium nitrate $\left(\mathrm{KNO}_{3}\right)$ before the onset of chilling and hydrogen cyanamide $\left(\mathrm{CH}_{2} \mathrm{~N}_{2}\right)$ after the trees had accumulated 600 chilling hours $(\mathrm{CH})$ to determine the effects on bud dormancy release, carbohydrate dynamics, and water content. For the carbohydrate and water content analyses, Japanese pear spur buds were collected after 0,300 , and $600 \mathrm{CH}$, and after the accumulation of 2000 , 4000, 6000, and 8000 growing degree hours (GDH) during the dormancy period. Bud burst and flowering were hastened by both $\mathrm{KNO}_{3}$ and $\mathrm{CH}_{2} \mathrm{~N}_{2}$ application, and both chemicals affected carbohydrate and water dynamics during dormancy. Sucrose concentration tended to increase during the chilling period, and to decrease under forcing conditions. Hexose concentrations increased in buds treated with $\mathrm{KNO}_{3}$, $\mathrm{CH}_{2} \mathrm{~N}_{2}$, or both, and were associated with advances in bud burst. Sorbitol concentration decreased early in buds treated with $\mathrm{CH}_{2} \mathrm{~N}_{2}$, suggesting rapid sorbitol catabolism. Water content gradually increased under forcing conditions in all buds, although those treated with both $\mathrm{KNO}_{3}$ and $\mathrm{CH}_{2} \mathrm{~N}_{2}$ exhibited the highest values. Accordingly, we recommend the use of $\mathrm{KNO}_{3}$ and $\mathrm{CH}_{2} \mathrm{~N}_{2}$, before and after chilling, respectively, to promote the release of bud dormancy and increase bud burst rate in 'Housui' Japanese pear grown in regions with mild winter conditions.

Keywords - Endodormancy. Water content. Sugar. Bud break.
Resumo - As árvores de pêra japonesa (Pyrus pyrifolia Nakai) foram tratadas com nitrato de potássio $\left(\mathrm{KNO}_{3}\right)$ antes do início do frio e cianamida hidrogenada $\left(\mathrm{CH}_{2} \mathrm{~N}_{2}\right)$ após terem acumulado 600 horas de frio (CH-chilling hours) para determinar seus efeitos na quebra de dormência de gemas, dinâmica de carboidratos e no conteúdo de água. Para as análises de carboidratos e conteúdo de água, foram coletadas gemas (esporôes) de pereira japonesa após 0, 300 e $600 \mathrm{CH}$, e após o acúmulo da soma térmica de 2000, 4000, 6000 e 8000 (GDH-growing degree hour) durante o período de dormência. A brotação e a floração foram aceleradas pela aplicação de $\mathrm{KNO}_{3}$ e $\mathrm{CH}_{2} \mathrm{~N}_{2}$, e ambos os produtos químicos afetaram a dinâmica de carboidratos e água durante a dormência. A concentração de sacarose tendeu-se a aumentar durante o período de frio e a diminuir sob condiçôes de forçamento. As concentraçōes de hexose aumentaram em gemas tratadas com $\mathrm{KNO}_{3}$, $\mathrm{CH}_{2} \mathrm{~N}_{2}$, ou ambos, e foram associadas com os avanços das brotaçôes. A concentração de sorbitol diminuiu antes em gemas tratadas com $\mathrm{CH}_{2} \mathrm{~N}_{2}$, sugerindo uma rápida degradação do sorbitol. $\mathrm{O}$ conteúdo de água aumentou gradualmente sob condiçóes de forçamento em todos os tratamentos, embora aqueles tratados com $\mathrm{KNO}_{3}$ e $\mathrm{CH}_{2} \mathrm{~N}_{2}$ exibiram os valores mais elevados. Sendo assim, recomenda-se o uso de $\mathrm{KNO}_{3}$ e $\mathrm{CH}_{2} \mathrm{~N}_{2}$, antes e depois do frio, respectivamente, para promover a quebra de dormência das gemas e aumentar a taxa de brotação em pereira japonesa cv. Housui cultivadas em regiôes sob condiçôes de inverno ameno. 
Palavras-chave - Endodormência. Conteúdo de água. Açúcar. Quebra de dormência.

Recebido em: 14 de setembro de 2016.

Aprovado em: 09 de novembro de 2016.

\section{INTRODUCTION}

Bud dormancy is an adaptive mechanism that allows woody plants to survive harsh winter conditions (FAUST et al., 1997). Several problems related to dormancy occur in temperate fruits trees such as kiwifruit (WALTON; CLARK; BOLDINGH, 1991), grapes (DOOKOOZLIAN et al., 1995; BEN MOHAMED et al., 2012), peaches, and nectarines (DOZIER et al., 1990) when they are grown in regions where winter conditions are not as cold as in their region of origin. In the Japanese pear (Pyrus pyrifolia Nakai), bud dormancy release is negatively affected in regions with mild winters, such as New Zealand (KINGSTON; KLINAC; EPENHUIJSEN, 1990) and Brazil (PETRI; HERTER, 2002).

Deciduous fruit trees need a certain amount of chilling time to overcome dormancy (LANG, 1996), and in some cases only a portion of this requirement can be satisfied via chilling substitutes (FAUST et al., 1997). Several chemicals have been reported to be effective in this regard, such as mineral oils (PETRI; STUKER, 1995), thiourea (KÜDEN; SON, 1997), calcium cyanamide (IWASAKI, 1980), hydrogen cyanamide (DOOKOOZLIAN et al., 1995; KUROKI et al., 2013) and potassium nitrate (EREZ; LAVEE; SAMISH, 1971; GEORGE; NISSEN, 1993; AKSOY et al., 1995). However, the trees' responses to these chemicals are variable, and depend on the chemical concentration and the time of application.

Hydrogen cyanamide $\left(\mathrm{CH}_{2} \mathrm{~N}_{2}\right)$ has been reported as one of the most effective dormancybreaking agents for many deciduous plant species (FUCHIGAMI; NEE, 1987), improving bud break in grapevines (DOOKOOZLIAN et al., 1995), peaches and nectarines (DOZIER et al., 1990), and Japanese pears (KUROKI et al., 2013). Effects of $\mathrm{CH}_{2} \mathrm{~N}_{2}$ on the carbohydrate metabolism have been reported for grapes (BEN MOHAMED et al., 2012), kiwifruit (RICHARDSON et al., 2010), and apples (CUTTING et al., 1991). However, few studies have been conducted on Japanese pears.

Potassium nitrate $\left(\mathrm{KNO}_{3}\right)$ has similarly been used as an alternative dormancy-breaking agent to promote bud break in peaches (EREZ; LAVEE; SAMISH, 1971; GEORGE; NISSEN, 1993), grapes (HASSAN, 2004), and apricots (AKSOY et al., 1995). Furthermore, $\mathrm{KNO}_{3}$ promotes changes in total free amino acid concentration in dormant grapevine buds (SUZUKI et al., 1997). In addition, this compound provides potassium, which is an essential element for plant growth that activates more than 60 enzymes, and is important in enabling plants to tolerate stresses such as high and low temperatures (MALVI, 2011)

Soluble sugars are important signaling molecules that are involved in various processes in a plant's lifecycle (SMEEKENS, 2000). In addition to their essential role as osmotic agents (SAKAI, 1960), protective aids for proteins and membranes (STEPONKUS et al., 1977), and in conferring tolerance for freezing (YOSHIOKA et al., 1988), carbohydrates are also the main source of energy for metabolic activities during dormancy, spring sprouting, and blooming (SHERSON et al., 2003). Dormancy in trees is also related to changes in water movement (WELLING; PALVA, 2006). Furthermore, water dynamics are essential for carbohydrates transport between source and sink during dormancy phase (MARAFON et al., 2011).

The effects of $\mathrm{KNO}_{3}$ and $\mathrm{CH}_{2} \mathrm{~N}_{2}$ application on carbohydrate and water content during bud dormancy in the Japanese pear under mild winter conditions are still poorly understood. Thus, the main objective of this study was to determine the effects of these compounds on bud break and on carbohydrate and water dynamics during bud dormancy in the 'Housui' Japanese pear under mild winter conditions.

\section{MATERIAL AND METHODS}

\subsection{Plant material}

The experiment was conducted in the boreal winter of 2012-2013 at the Agricultural and Forestry Research Center of University of Tsukuba, Tsukuba, Japan $\left(36^{\circ} \mathrm{N}, 140^{\circ} \mathrm{E}\right)$, using 'Housui' Japanese pear trees grown in pots. The experimental design was completely randomized, with four treatments (water [control], $\mathrm{KNO}_{3}, \mathrm{CH}_{2} \mathrm{~N}_{2}$, and a combination of $\mathrm{KNO}_{3}$ and $\mathrm{CH}_{2} \mathrm{~N}_{2}$ ) in three replicates (three trees per replicate). Spur buds 
were treated with $4 \% \mathrm{KNO}_{3}$, using a hand sprayer, before the onset of chilling (22 October 2012). The trees were maintained under field conditions until they had accumulated 600 chilling hours $(\mathrm{CH})$, after which $1 \% \mathrm{CH}_{2} \mathrm{~N}_{2}$ was applied with a hand sprayer until the drip point. The trees were then subjected to forcing temperatures (minimum of $13{ }^{\circ} \mathrm{C}$ ) in a greenhouse. $\mathrm{CH}$ were classified as the number of hours below $7.2{ }^{\circ} \mathrm{C}$ under field conditions. The number of growing degree hours (GDH) was calculated by subtracting $4.5^{\circ} \mathrm{C}$ from each hourly temperature, and then summing the values (RICHARDSON et al., 1975). Spur buds were collected at 0,300 , or $600 \mathrm{CH}$, and at 2000, 4000,6000 , or $8000 \mathrm{GDH}$, frozen in liquid nitrogen, and kept in an ultra-freezer $\left(-80^{\circ} \mathrm{C}\right)$ for further analysis.

\subsection{Determination of bud burst, flowering and number of flowers per cluster}

Trees were examined for bud burst and flowering every two days after these were subjected to forcing conditions in the greenhouse. Bud burst was identified as the point when buds reached the phenological stage C3 (COUTANCEAU, 1971; CALVET; GUIRBAL, 1979), and trees were recorded as flowering when they had at least one completely open flower. The number of flowers per cluster was counted once the petals had one completely opened flower.

\subsection{Water content determination}

Water content was measured by drying $500 \mathrm{mg}$ of fresh spur bud samples at $80{ }^{\circ} \mathrm{C}$ in an oven for 24 hours. Dried samples were weighed and water content was calculated according to the formula: Water content $=(\mathrm{FW}-\mathrm{DW}) / \mathrm{FW} \times 100$, where $\mathrm{FW}$ is fresh weight and DW is dry weight, both expressed in grams.

\subsection{Determination of sugar concentration}

To determine the sugar content, approximately $300 \mathrm{mg}$ of frozen spur buds were weighed accurately, ground using liquid nitrogen in a mill (ForceMill; Osaka Chemical, Osaka, Japan), and extracted twice with $6 \mathrm{~mL}$ of $80 \%$ ethanol. After the addition of $1 \mathrm{~mL}$ of pentaerythritol (1\%) as an internal standard, the extract was evaporated in a vacuum at $40{ }^{\circ} \mathrm{C}$. To remove phenolic compounds, three milligrams of polyvinylpolypyrrolidone (PVPP) was added into $1 \mathrm{~mL}$ aliquots of the extract, then centrifuged at $14.000 \mathrm{rpm}$ for $10 \mathrm{~min}$ and filtered through a Millipore filter $(0.45 \mu \mathrm{m})$ attached to a syringe. $20-\mu \mathrm{L}$ samples of extract solution were then subjected to high-performance liquid chromatography (HPLC) using an auto-sampler with a pre-column (Shin-pack SPR-Ca; Shimadzu, Japan), a packed column (SC 1011, SHODEX; Showa Denko K.K., Tokyo, Japan), and a refractive index detector (RI-101, SHODEX; Showa Denko K.K.). Ultra-pure water $(18 \mathrm{~m} \Omega)$ was used for the mobile phase, and the equipment was set to a flow rate of $1.0 \mathrm{~mL} \mathrm{~min}{ }^{-1}$ and a column temperature of $80{ }^{\circ} \mathrm{C}$. Carbohydrate content was quantified based on calculations of peak area obtained from regression curves of standards.

\subsection{Determination of starch concentration}

Starch was quantified using a total starch kit (AOAC Official Method 996.11; Megazyme International Ireland, Bray, Ireland). The pellet remaining after the ethanol extraction for sugar determination was oven-dried overnight at $60{ }^{\circ} \mathrm{C}$. The dried samples were stirred in a vortex mixer with $0.2 \mathrm{~mL}$ of $80 \%(\mathrm{v} / \mathrm{v})$ ethanol. Immediately, 3

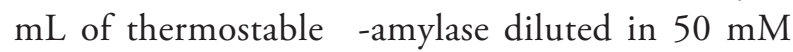
MOPS buffer ( $\mathrm{pH} 7.0$ ) was added, and the samples were incubated for $12 \mathrm{~min}$ in boiling water. The tubes were placed in a water bath at $50{ }^{\circ} \mathrm{C}$ and 4 $\mathrm{mL}$ of $200 \mathrm{mM}$ sodium acetate buffer ( $\mathrm{pH} 4.5$ ) was added, followed by $0.1 \mathrm{~mL}$ of amyloglucosidase, and incubated for $30 \mathrm{~min}$. The samples were then adjusted to $10 \mathrm{~mL}$ with deionized water, followed by centrifugation at $3000 \mathrm{rpm}$. Duplicated $0.2-\mathrm{mL}$ aliquots of the diluted solution were transferred to a glass tube $(16 \times 100 \mathrm{~mm})$ and $3 \mathrm{~mL}$ of glucose oxidase/peroxidase (GOPOD) reagent was added, followed by incubation for $20 \mathrm{~min}$ at $50{ }^{\circ} \mathrm{C}$. $\mathrm{D}$-glucose was used as the standard, and distilled water was used as the blank. Absorbance at $510 \mathrm{~nm}$ was determined using a UV/VIS spectrophotometer (V-550; Jasco, Tokyo, Japan).

\subsection{Statistical analysis}

Means and standard errors were calculated from the replicates. The data were analyzed using one-way analysis of variance (ANOVA), and the means were compared using the Tukey-Kramer test at 5\% of probability in JMP 5.0.1. All percentage data were arc-sine transformed before analysis. The graphics were produced using Graphpad Prism 5.0 (GraphPad Software). 


\section{RESULTS AND DISCUSSION}

To replicate mild winter conditions, trees were exposed to $600 \mathrm{CH}$ that accounts to $80 \%$ of the 750 $\mathrm{CH}\left(\leq 7.2^{\circ} \mathrm{C}\right)$ necessary to release endodormancy in Japanese pear (NISHIMOTO; KISAKI; FUJISAKI, 1995). Knowing that potassium provides plants tolerance against stress, such as high and low temperatures (MALVI, 2011), we tried applying $\mathrm{KNO}_{3}$ before the chilling accumulation period to serve not only as a bud break agent, but also as an aid for buds in tolerating low temperatures.

The application of $\mathrm{KNO}_{3}$ before and of $\mathrm{CH}_{2} \mathrm{~N}_{2}$ after chilling hastened bud burst relative to the control trees (Fig. 1A). Bud burst under forcing conditions started 16 days after spraying of $\mathrm{CH}_{2} \mathrm{~N}_{2}$ and the combined treatment, whereas it took 22 days in the $\mathrm{KNO}_{3}$ treatment and 24 days in the control. In all trees, except those in the control treatment, $100 \%$ of buds burst; bud burst in the control was $93 \%$. Application of $\mathrm{KNO}_{3}$ and $\mathrm{CH}_{2} \mathrm{~N}_{2}$ advanced the onset of flowering in spur buds relative to the control (Fig. 1B). Flowering began first in the $\mathrm{CH}_{2} \mathrm{~N}_{2}$ and combined treatments, followed by the $\mathrm{KNO}_{3}$ and control treatments. Treatment of 'Housui' Japanese pear trees with $\mathrm{KNO}_{3}$ and/or $\mathrm{CH}_{2} \mathrm{~N}_{2}$ resulted in earlier bud burst and flowering than in the control. Similar results had been reported by George and Nissen (1993) and Aksoy et al. (1995), who found an advance in bud break as a result of using $\mathrm{KNO}_{3}$ in a lowchill peach cultivar and in apricots, respectively. In another study, treating buds with $\mathrm{KNO}_{3}$ resulted in a bud break percentage similar to that following $\mathrm{CH}_{2} \mathrm{~N}_{2}$ treatment in 'Perlette 'grapes (HASSAN, 2004). In our results with Japanese pear, $\mathrm{KNO}_{3}$ applied before the chilling period, in combination with $\mathrm{CH}_{2} \mathrm{~N}_{2}$ sprayed after $600 \mathrm{CH}$ had accumulated, resulted in earlier bud burst than $\mathrm{KNO}_{3}$ treatment alone, which is similar to the findings of another study, in which bud break was advanced when $\mathrm{KNO}_{3}$ was combined with other chemicals (EREZ; LAVEE; SAMISH, 1971). The effect of $\mathrm{CH}_{2} \mathrm{~N}_{2}$ on bud break in Japanese pear flower buds depends on its concentration, accumulated chilling, and the cultivar (KUROKI et al., 2013). A similar tendency has been observed in other studies, where $\mathrm{CH}_{2} \mathrm{~N}_{2}$ advanced bud break in grapevines (DOOKOOZLIAN et al., 1995) and in peaches and nectarines (DOZIER et al., 1990).
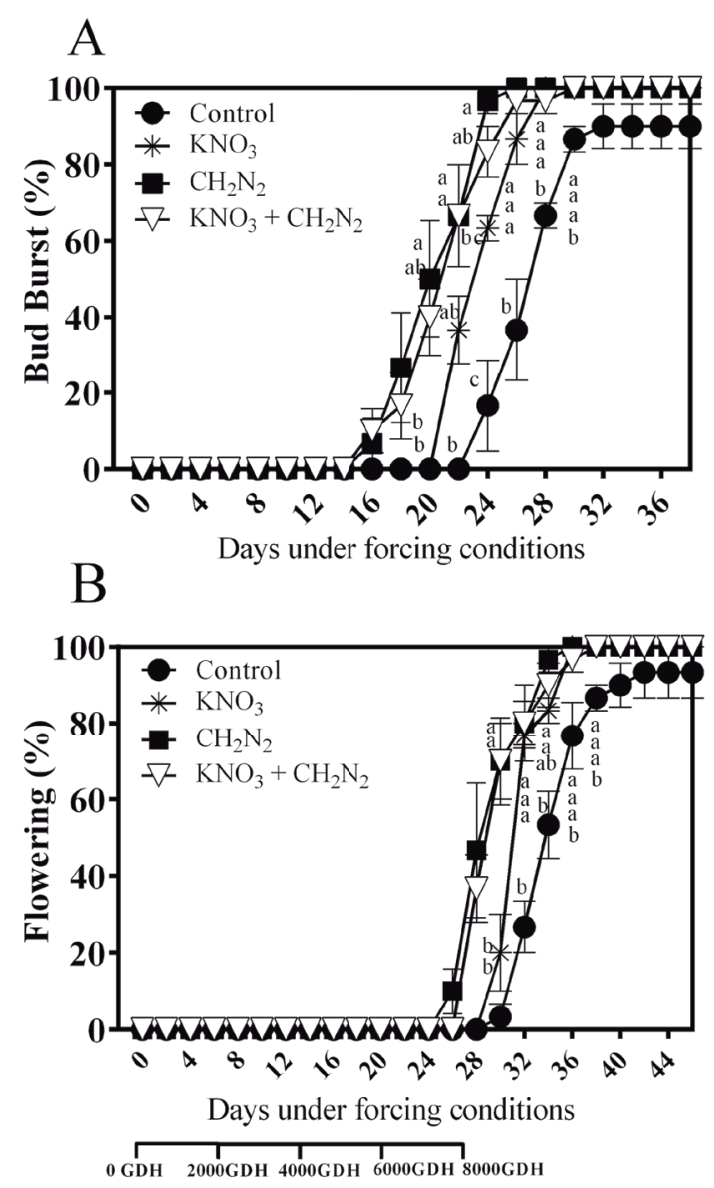

Figure 1. Bud burst (A) and flowering (B) in Japanese pear spur buds treated with pure water (control, closed circles), $\mathrm{KNO}_{3}$ before chilling (stars), $\mathrm{CH}_{2} \mathrm{~N}_{2}$ after chilling (closed squares), or both $\mathrm{KNO}_{3}$ and $\mathrm{CH}_{2} \mathrm{~N}_{2}$ (open triangles) under mild winter conditions. Bud burst was classified as the point when buds reached phenological stage $\mathrm{C} 3$, and flowering was recorded as the point when a tree had at least one completely open flower. Different letters indicate significant differences among treatments at each sampling time. Means compared by Tukey-Kramer test at $5 \%$ probability, $\pm \mathrm{SE}(\mathrm{n}=3)$.

The number of flowers per cluster (approx. four) was similar across treatments (Figure 2). The number of flowers per cluster was not affected by the treatment. In contrast, it has been reported that the application of $\mathrm{CH}_{2} \mathrm{~N}_{2}$ to kiwifruit increased the total number of flowers (MCPHERSON et al., 2001).

The water content of the buds remained low during the chilling period, and then gradually increased under forcing conditions (Figure 3). Also, it was observed that under forcing conditions, the water content of the buds at $8000 \mathrm{GDH}$ in the $\mathrm{CH}_{2} \mathrm{~N}_{2}, \mathrm{KNO}_{3}$, and combined treatments was higher than that of the control buds. Simóes et al. (2014) observed similar results, where water content increased in 'Housui' Japanese pear buds throughout dormancy. It has been reported that $\mathrm{CH}_{2} \mathrm{~N}_{2}$ might increase the influx of water into buds, and this accumulation of water may assist in advancing the release of bud dormancy (YOOYONGWECH et al., 
2012). Thus, the application of $\mathrm{KNO}_{3}$ and $\mathrm{CH}_{2} \mathrm{~N}_{2}$ may have changed the water dynamics, leading to the earlier bud burst in this study.

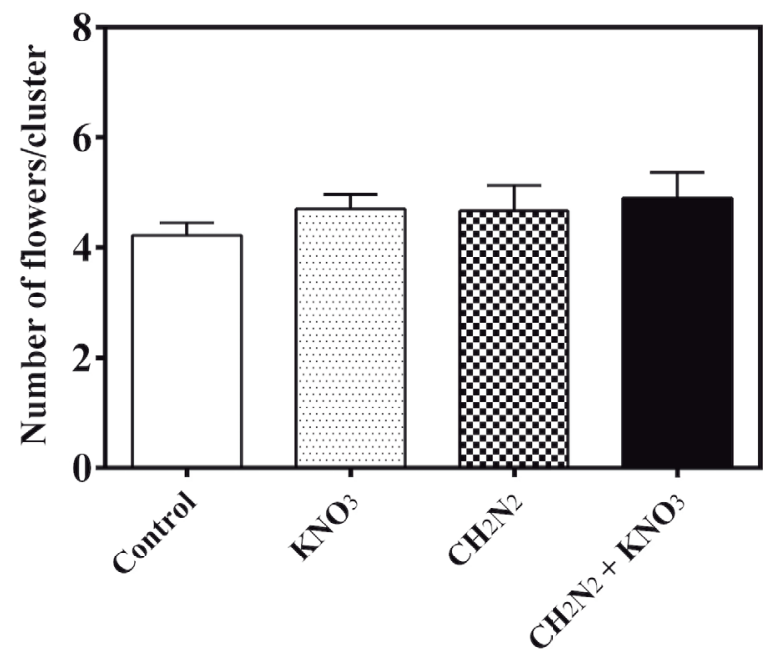

Figure 2. Number of flowers per cluster in Japanese pear spur buds treated with pure water (control, white), $\mathrm{KNO}_{3}$ before chilling (stipples), $\mathrm{CH}_{2} \mathrm{~N}_{2}$ after chilling (checks), or both $\mathrm{KNO}_{3}$ and $\mathrm{CH}_{2} \mathrm{~N}_{2}$ (black) under mild winter conditions. Different letters indicate significant differences between treatments at each sampling time. Means compared by Tukey-Kramer test at $5 \%$ probability, $\pm \operatorname{SE}(n=3)$.

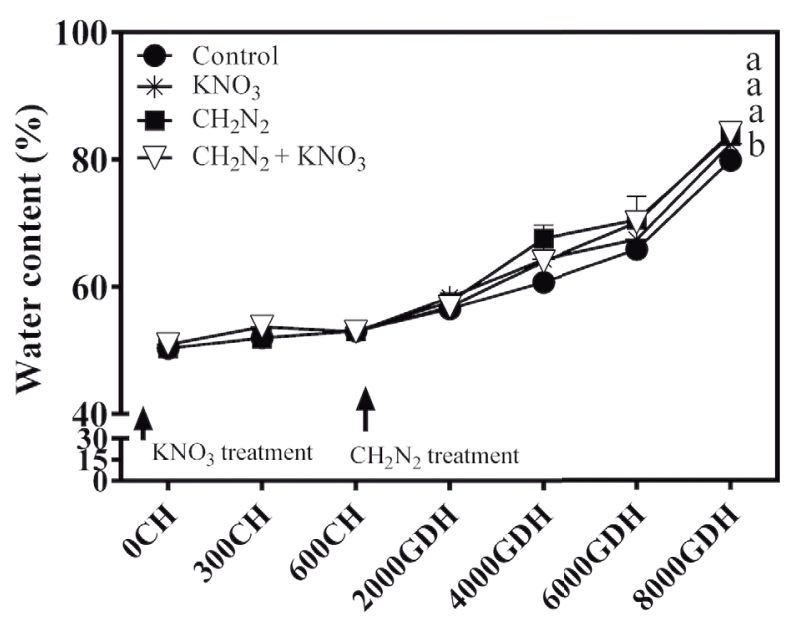

Figure 3. Water content of Japanese pear spur buds treated with pure water (control, closed circles), $\mathrm{KNO}_{3}$ before chilling (stars), $\mathrm{CH}_{2} \mathrm{~N}_{2}$ after chilling (closed squares), or both $\mathrm{KNO}_{3}$ and $\mathrm{CH}_{2} \mathrm{~N}_{2}$ (open triangles) under mild winter conditions. $\mathrm{CH}$ (chilling hours): accumulated hours of chilling $\leq 7.2^{\circ} \mathrm{C} ; \mathrm{GDH}$ (growing degree hours): accumulated temperature $\left({ }^{\circ} \mathrm{C}\right)$ of warming. Different

(growing degree hours): accumulated temperature $\left({ }^{\circ} \mathrm{C}\right)$ of warming. Different
letters indicate significant differences between treatments at each sampling time.
Means compared by Tukey-Kramer test at $5 \%$ probability, \pm SE $(n=3)$.

The soluble carbohydrate content of the buds fluctuated between the different phases of dormancy, tending to increase during the chilling period and decrease under forcing conditions. Application of $\mathrm{KNO}_{3}$ negatively affected sucrose accumulation at $600 \mathrm{CH}$ (Figure 4). Under forcing conditions, the control buds had the highest sucrose content after $4000 \mathrm{GDH}$, which then gradually decreased. The $\mathrm{KNO}_{3}$-treated buds had higher sucrose concentrations than the combined treatment at 6000
$\mathrm{GDH}$, and the highest concentration of all four treatments at $8000 \mathrm{GDH}$. Sucrose concentration increased during the endodormancy phase under chilling. According to Yoshioka et al. (1988), starch is degraded by amylase and metabolized into sucrose under the influence of cold temperatures, and that soluble carbohydrates play an important role in increasing freezing tolerance during winter and in providing energy for growth in spring.

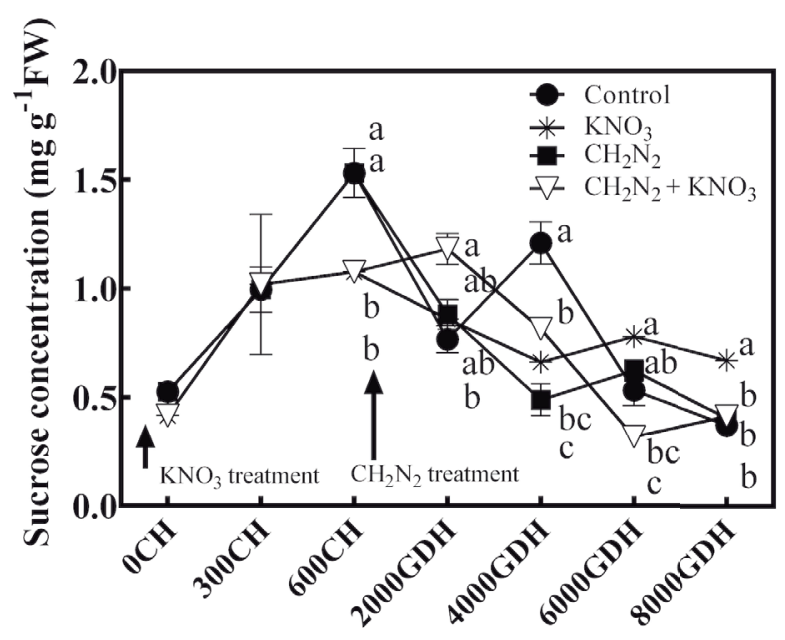

Figure 4. Sucrose concentration (mg. $\mathrm{g}^{-1}$ fresh weight) in Japanese pear Figure 4. Sucrose concentration (mg.g $\mathrm{g}^{-1}$ fresh weight) in Japanese pear spur buds treated with pure water (control, closed circles), $\mathrm{KNO}_{3}$ before chilling (stars), $\mathrm{CH}_{2} \mathrm{~N}_{2}$ after chilling (closed squares), or both $\mathrm{KNO}_{3}$
and $\mathrm{CH}_{2} \mathrm{~N}_{2}$ (open triangles) after accumulation of chilling hours under mild winter conditions. $\mathrm{CH}$ (chilling hours): accumulated hours of chilling $\leq 7.2^{\circ} \mathrm{C}$; GDH (growing degree hours) accumulated temperature $\left({ }^{\circ} \mathrm{C}\right)$ of warming. Different letters indicate significant differences among treatments at each sampling time. Means compared by Tukey-Kramer test at $5 \%$ probability, \pm SE $(n=3)$.

Fructose concentration remained stable and similar across the treatments until forcing conditions began (Figure 5). The $\mathrm{KNO}_{3}, \mathrm{CH}_{2} \mathrm{~N}_{2}$, and combined treatments resulted in a gradual increase in fructose concentration from $4000 \mathrm{GDH}$, while in control buds the increase was only found at $8000 \mathrm{GDH}$. Glucose concentration remained low during chilling accumulation under field conditions, but increased under forcing conditions (Fig. 6). From 6000 GDH onwards, the control buds exhibited the lowest glucose concentration. In our experiment, glucose and fructose tended to increase, and sucrose to decline, as bud burst began under forcing conditions. A rapid decrease in sucrose and a simultaneous increase in hexose concentrations during spring are the earliest signs of high metabolic activity and resumption of growth (RICHARDSON et al., 2010). In addition, bud break is followed by the rapid consumption of sucrose, glucose and fructose (BEN MOHAMED et al., 2012). The delayed bud burst in our control trees was correlated with smaller increases in hexose 
concentrations during the forcing period. Thus, the movement and availability of soluble carbohydrates appears to be essential for the resumption of growth, and the application of both $\mathrm{CH}_{2} \mathrm{~N}_{2}$ and $\mathrm{KNO}_{3}$ may enhance these dynamics, leading to early bud burst (and high rates of bud burst) in the Japanese pear.

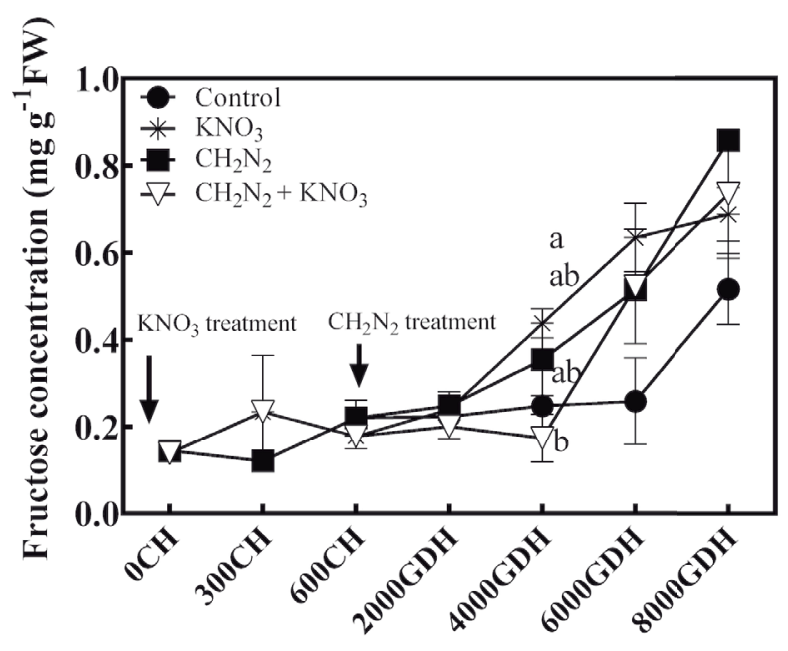

Figure 5. Fructose concentration (mg. $\mathrm{g}^{-1}$ fresh weight) in Japanese pear spur buds treated with pure water (control, closed circles), $\mathrm{KNO}_{3}$ before chilling (stars), $\mathrm{CH}_{2} \mathrm{~N}_{2}$ after chilling (closed squares), or both $\mathrm{KNO}_{3}$ and $\mathrm{CH}_{2} \mathrm{~N}_{2}$ (open triangles) after accumulation of chilling hours under mild winter conditions. $\mathrm{CH}$ (chilling hours): accumulated hours of chilling $\leq 7.2^{\circ} \mathrm{C}$; GDH (growing degree hours) accumulated temperature $\left({ }^{\circ} \mathrm{C}\right)$ of warming. Different letters indicate significant differences among treatments at each sampling time. Means compared by Tukey-Kramer test at $5 \%$ probability, \pm SE $(n=3)$.

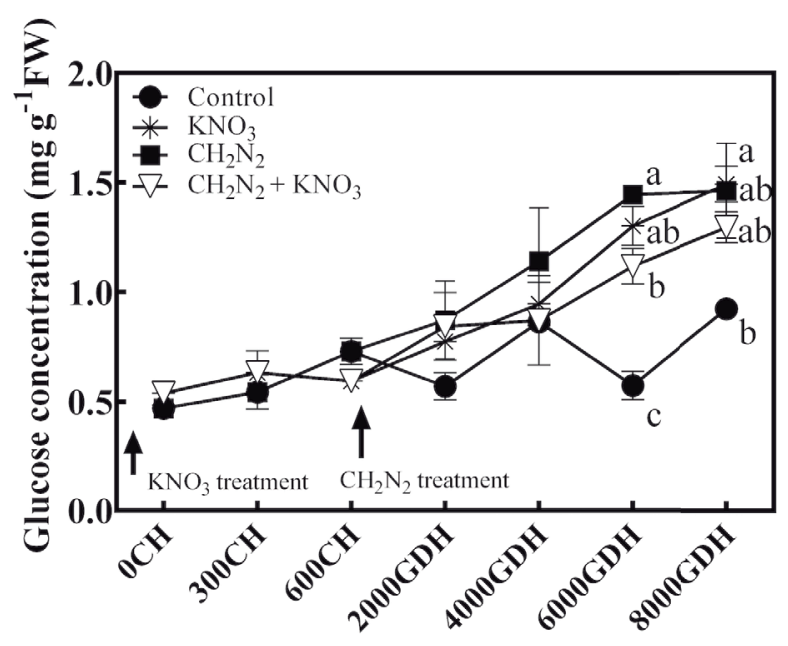

Figure 6. Glucose concentration (mg. $\mathrm{g}^{-1}$ fresh weight) in Japanese pear spur buds treated with pure water (control, closed circles), $\mathrm{KNO}_{3}$ before chilling (stars), $\mathrm{CH}_{2} \mathrm{~N}_{2}$ after chilling (closed squares), or both $\mathrm{KNO}_{3}$ and $\mathrm{CH}_{2} \mathrm{~N}_{2}$ (open triangles) after accumulation of chilling hours under mild winter conditions. CH (chilling hours): accumulated hours of chilling $\leq 7.2^{\circ} \mathrm{C} ; \mathrm{GDH}$ (growing degree hours) accumulated
(g) chilling $\leq 7.2^{\circ} \mathrm{C}$; GDH (growing degree hours) accumulated
temperature $\left({ }^{\circ} \mathrm{C}\right)$ of warming. Different letters indicate significant differences among treatments at each sampling time. Means compared by Tukey-Kramer test at $5 \%$ probability, $\pm \operatorname{SE~}(n=3)$.

Sorbitol concentration in buds increased during chilling accumulation, and gradually decreased under forcing conditions (Figure 7). In the $\mathrm{CH}_{2} \mathrm{~N}_{2}$ and combined treatments, the sorbitol concentration increased until the onset of forcing conditions, decreased rapidly after $2000 \mathrm{GDH}$, and remained low until the end of the trial at $8000 \mathrm{GDH}$, whereas in the buds in the control and $\mathrm{KNO}_{3}$ treatments it decreased more slowly. The application of $\mathrm{CH}_{2} \mathrm{~N}_{2}$ to buds after the accumulation of $600 \mathrm{CH}$ caused the sorbitol concentration to decrease more rapid than in other buds. Similarly, $\mathrm{CH}_{2} \mathrm{~N}_{2}$ application to apple trees promoted earlier bud break and a marked decrease in sorbitol concentration (CUTTING et al., 1991). This suggests that $\mathrm{CH}_{2} \mathrm{~N}_{2}$ application leads to rapid sorbitol catabolism, which provides energy and thereby advances bud break. This hypothesis is supported by our results. Sorbitol and sucrose concentration in the buds increased during the endodormancy period, i.e. under chilling; as noted above, these concentrations may be strongly correlated with the development of freezing tolerance (YOSHIOKA et al., 1988; ITO; SAKAMOTO; MORIGUCHI, 2013). Sorbitol is often the primary carbohydrate that is translocated in fruit trees in the Rosaceae family (LOESCHER; EVERARD, 1996), and carbohydrate is transported from source to sink in this form in the Japanese pear during endodormancy (ITO; SAKAMOTO; MORIGUCHI, 2012). The sucrose and sorbitol accumulated during the endodormancy period is converted into glucose and fructose for the resumption of growth and flower development. Although it has been reported that just a small quantity of sorbitol is sufficient to satisfy the high demand for carbon and energy during the early stages of bud break in peaches (MAUREL et al., 2004), the lack of capacity to metabolize sucrose and sorbitol to provide the required hexoses under cold deprivation conditions is associated with floral necrosis (BONHOMME et al., 2005). We therefore suggest that the delay in bud burst and the occurrence of bud abortion in the control trees were caused by low rates of increase in hexose concentrations.

The starch concentration in the buds remained stable during the entire study period (Figure 8). During the chilling period, buds not treated with $\mathrm{KNO}_{3}$ showed a decrease in starch concentration at $400 \mathrm{CH}$, followed by an increase at $600 \mathrm{CH}$. After the chilling period, $\mathrm{CH}_{2} \mathrm{~N}_{2}$ application caused a slight decrease in the starch concentration at the onset of forcing conditions, after which starch content remained unchanged. Buds in the combined treatment exhibited the highest starch concentration at the beginning of forcing conditions, and then tended to decrease. Although we did not observe a 
clear trend in this study, it has been reported that the completion of endodormancy is associated with increasing starch and decreasing sugar concentrations in the Japanese pear (HONJO et al., 2002). In contrast, high starch and low soluble sugar concentrations have been observed during the onset of endodormancy in grapevines (BEN MOHAMED et al., 2010). Furthermore, accumulated starch is used for the resumption of Japanese pear growth in spring (GEMMA, 1995), and an increase in $\triangle$-amylase activity is associated with the release of bud dormancy in grapevines (BEN MOHAMED et al., 2012). The effects of $\mathrm{KNO}_{3}$ on sugar metabolism remain unclear, although it can be hypothesized that the involvement of potassium is important because of its function in activating more than 60 enzymes, including starch synthase (MALVI, 2011). Hence, carbohydrate dynamics play an important role during bud endodormancy and dormancy release, and further research is needed to clarify the effects of $\mathrm{CH}_{2} \mathrm{~N}_{2}$ and $\mathrm{KNO}_{3}$ on the physiological aspects during bud dormancy in the Japanese pear under mild winter conditions.

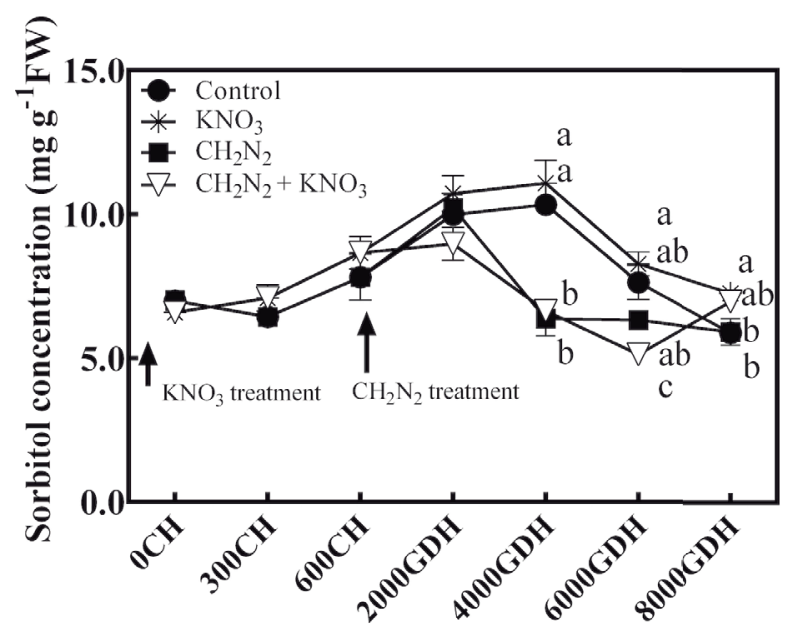

Figure 7. Sorbitol concentration (mg. $\mathrm{g}^{-1}$ fresh weight) in Japanese pear spur buds treated with pure water (control, closed circles), $\mathrm{KNO}_{3}$ before spur buds treated with pure water (control, closed circles), $\mathrm{KNO}_{3}$ before
chilling (stars), $\mathrm{CH}_{2} \mathrm{~N}_{2}$ after chilling (closed squares), or both $\mathrm{KNO}_{3}$ and $\mathrm{CH}_{2} \mathrm{~N}_{2}$ (open triangles) after accumulation of chilling hours under and $\mathrm{CH}_{2} \mathrm{~N}_{2}$ (open triangles) after accumulation of chilling hours under chilling $\leq 7.2^{\circ} \mathrm{C}$; GDH (growing degree hours) accumulated temperature $\left({ }^{\circ} \mathrm{C}\right)$ of warming. Different letters indicate significant differences among treatments at each sampling time. Means compared by Tukey-Kramer test at $5 \%$ probability, $\pm \operatorname{SE}(n=3)$.

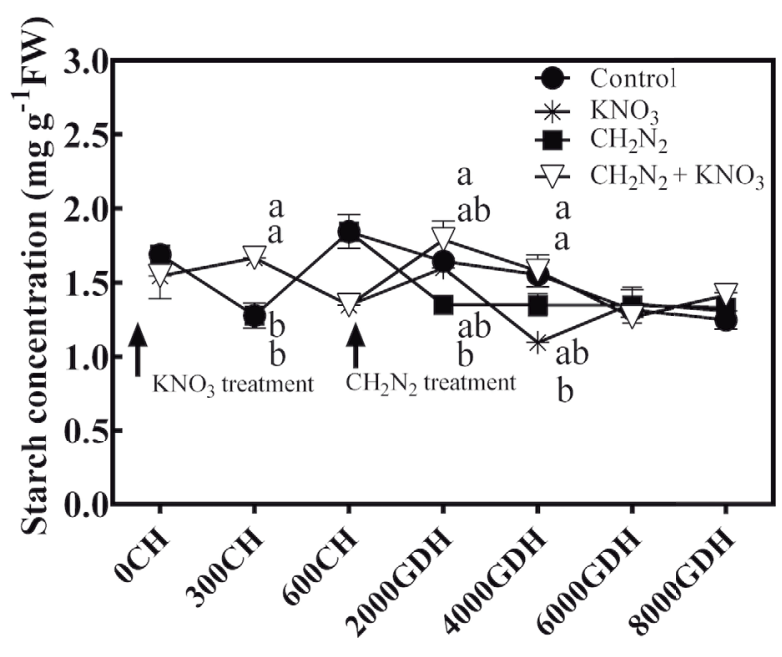

Figure 8. Starch concentration (mg. $\mathrm{g}^{-1}$ fresh weight) in Japanese pear spur buds treated with pure water (control, closed circles), $\mathrm{KNO}_{3}$ before chilling (stars), $\mathrm{CH}_{2} \mathrm{~N}_{2}$ after chilling (closed squares), or both $\mathrm{KNO}_{3}$ and $\mathrm{CH}_{2} \mathrm{~N}_{2}$ (open triangles) after accumulation of chilling hours under mild winter conditions. $\mathrm{CH}$ (chilling hours): accumulated hours of chilling $\leq 7.2^{\circ} \mathrm{C}$; GDH (growing degree hours) accumulated temperature $\left({ }^{\circ} \mathrm{C}\right)$ of warming. Different letters indicate significant differences among treatments at each sampling time. Means compared by Tukey-Kramer test at $5 \%$ probability, \pm SE $(n=3)$.

\section{CONCLUSIONS}

Application of $\mathrm{KNO}_{3}$ before the onset of chilling and of $\mathrm{CH}_{2} \mathrm{~N}_{2}$ after the accumulation of $600 \mathrm{CH}$ to Japanese pear spur buds hastened bud break. $\mathrm{CH}_{2} \mathrm{~N}_{2}$ and $\mathrm{KNO}_{3}$ increased water content and hexose concentrations, which resulted in improvements in bud burst under forcing conditions. The application of $\mathrm{CH}_{2} \mathrm{~N}_{2}$ led to a rapid sorbitol catabolism under forcing conditions. We, therefore recommend using both $\mathrm{KNO}_{3}$ as an alternative dormancy-breaking agent before the onset of chilling and employing $\mathrm{CH}_{2} \mathrm{~N}_{2}$ after chilling accumulation to increase bud break rates in Japanese pear trees grown under mild winter conditions.

\section{ACKNOWLEDGEMENTS}

We are grateful to the Tsukuba experimental orchard, Agricultural and Forestry Research Center, University of Tsukuba for allowing us to conduct the field experiment. This work was supported by Ministry of Education, Culture, Sports, Sciences and Technology (MEXT): Japan, and by JSPS KAKENHI (Grant-in-Aid for Scientific Research (B) Grant Number 25292019. We also want to express gratitude for Dr. Robson Ryu Yamamoto for reviewing the paper and for Ms. Michelle Jane Genoveso for the editing part. 


\section{REFERENCES}

AKSOY, U. et al. Effect of potassium nitrate and hydrogen cyanamide on apricot. X International Symposium on Apricot Culture. Acta horticulturae, v. 384, p. 431-440, 1995.

BEN MOHAMED, $\mathrm{H}$. et al. Carbohydrate changes during dormancy release in Superior Seedless grapevine cuttings following hydrogen cyanamide treatment. Scientia Horticulturae, v. 140, p. 19-25, 2012.

BEN MOHAMED, H. et al. Biochemical changes in dormant grapevine shoot tissues in response to chilling: possible role in dormancy release. Scientia Horticulturae, v. 124, p. 440-447, 2010.

BONHOMME, M.; et al. Influences of cold deprivation during dormancy on carbohydrate contents of vegetative and floral primordia and nearby structures of peach buds (Prunus persica L. Batch). Scientia Horticulturae, v. 105, p. 223-240, 2005.

CALVET, C.; GUIRBAL, M. Manual d'arboriculture fruitère. Paris: J. B. Baillière, 1979

COUTANCEAU, M. Fruticultura técnica y economía de lós cultivos de rosáceas Leñosas productoras de fruta. Barcelona: Oikostau, 1971.

CUTTING, J.G.M. et al. Changes in xylem constituents in response to rest-breaking agents applied to apple before budbreak. Journal of the American Society for Horticultural Science, v. 116, p. 680-683, 1991.

DOOKOOZLIAN, N.; WILIAMS, E. Chilling exposure and hydrogen cyanamide interact in breaking dormancy of grape buds. Horticultural Science, v. 30, p. 1244$1247,1995$.

DOZIER, W.A. et al. Hydrogen cyanamide induces budbreak of peaches and nectarines following inadequate chilling. HortScience, v. 25, p. 1573-1575, 1990.

EREZ, A.; LAVEE, S.; SAMISH, R.M. Improved methods for breaking rest in the peach and other deciduous fruit species. Journal of the American Society for Horticultural Science, v. 96, p. 519-522, 1971.

FAUST, M. et al. Bud dormancy in perennial fruit trees: physiological basis for dormancy induction, maintenance, and release. HortScience, v. 32, p. 623-629, 1997.

FUCHIGAMI, L.H.; NEE, C. Degree growth stage model and rest breaking mechanisms in temperate woody perennials. HortScience, v. 22, p. 836-845, 1987.
GEMMA, H. Dormancy breaking in Japanese pears grown in a heated greenhouse. Acta horticulturae, v. 395, p. $57-$ 68, 1995.

GEORGE, A.P.; NISSEN, R.J. Effect of growth regulants on defoliation, flowering, and fruit maturity of the low chill peach cultivar 'Flordaprince' in subtropical Australia. Australian Journal of Experimental Agriculture, v. 33, p. 787-795, 1993.

HASSAN, A. Effect of hydrogen cyanamide (Dormex) and potassium nitrate on bud break, and quality of perlette grape in Jericho in the Jordan Valley. Agricultural Science, v. 31, n. 1, p. 46-52, 2004.

HONJO, H. et al. Effect of intermittent periods on bud break and carbohydrate content of Japanese pear (Pyrus pyrifolia Nakai) in different endodormancy stages. Acta horticulturae, v. 587, p. 397-403, 2002.

ITO, A.; SAKAMOTO, D.; MORIGUCHI, T. Carbohydrate metabolism and its possible roles in endodormancy transition in Japanese pear. Scientia Horticulturae, v. 144, p. 187-194, 2012.

ITO, A.; SAKAMOTO, D.; MORIGUCHI, T. Effects of dormancy progression and low-temperature response on changes in the sorbitol concentration in xylem sap of Japanese pear during winter season. Tree Physiology, v. 33, p. 398-408, 2013.

IWASAKI, K. Effects of bud scale removal, calcium cyanamide, GA3, and ethephon on the bud break of 'Muscat of Alexandria' grape (Vitis vinifera L). Journal of the Japanese Society for Horticultural Science, v. 48, p. 385-398, 1980.

KINGSTON, C.M.; KLINAC, D.J.; EPENHUIJSEN, C.W. Floral disorders of nashi (Pyrus serotina) grown in New Zealand. New Zealand Journal of Crop and Horticultural Science, v. 18, p. 157-159, 1990.

KÜDEN, A.B.; SON, L. Dormancy breaking experiments on apricots. Acta horticulturae, v. 441, p. 153-158, 1997.

KUROKI, K. et al. Effect of hydrogen cyanamide on breaking flower bud endodormancy and flowering period of major Japanese Pear cultivars. Horticultural Research Japan, v. 12, n. 2, p. 179-185, 2013.

LANG, G.A. Plant Dormancy: Physiology, Biochemistry and Molecular Biology. Wallingford: CAB International, 1996.

LOESCHER, W.H.; EVERARD, J.D. Sugar alcohol metabolism in sinks and sources. In: ZAMSKI, E.; SCHAFFER, A.A. (ed.). Photoassimilate distribution 
in plants and crops. New York: Marcel Dekker, 1996. p. $185-207$.

MALVI, U.R. Interaction of micronutrients with major nutrients with special reference to potassium. Karnataka Journal of Agricultural Science, v. 24, p. 106-109, 2011.

MARAFON, A.C. et al.. Chilling privation during dormancy period and carbohydrate mobilization in Japanese pear trees. Scientia Agricola, v. 68, n. 4, p. 462468, 2011.

MAUREL, K. et al. Trophic control of bud break in peach (Prunus persica) trees: a possible role of hexoses. Tree Physiology, v. 24, p. 579-588, 2004.

MCPHERSON, H.G. et al. Effects of hydrogen cyanamide on budbreak and flowering in kiwifruit (Actinidia deliciosa 'Hayward'). New Zealand Journal of Crop and Horticultural Science, v. 29, p. 277-285, 2001.

NISHIMOTO, N.; KISAKI, K.; FUJISAKI, M. Estimation of chilling requirement of using a grafting method in Japanese pear. Journal of the Japanese Society for Horticultural Science, v. 64, p. 140-142, 1995.

PETRI, J.L.; STUKER, H. Effect of mineral oil and hydrogen cyanamide concentrations on apple dormancy, cv. Gala. Acta Horticulturae, v. 395, p. 161-168, 1995

PETRI, J.L.; HERTER, F. Nashi pear (Pyrus pyrifolia) dormancy under mild temperate climate conditions. Acta Horticulturae, v. 587, p. 353-361, 2002.

RICHARDSON, A.C. et al Carbohydrate changes in kiwifruit buds during the onset and release from dormancy. Scientia Horticulturae, v. 124, n. 4, p. 463-468, 2010.

RICHARDSON, E.A. et al Pheno-climatography of spring peach bud development. HortScience, v. 10, n. 3, p. 236-237, 1975.

SAKAI, A. Relation of sugar content to frost hardiness in plants. Nature, v. 185, p. 698-699, 1960.

SAMISH, R.M. Dormancy in plants woody plants. Annual Review of Plant Physiology, v. 5, p. 183-203, 1954.

SHERSON, S.M. et al Roles of cell wall invertases and monosaccharide transporters in the growth and development of Arabidopsis. Journal of Experimental Botany, v. 54, p. 525-531, 2003.

SIMÓES, F. et al. Water Content and Carbohydrate Dynamics of Pear Trees during Dormancy in Southern Brazil. Acta Horticulturae, v. 1058, p. 305-312, 2014.
SMEEKENS, S. Sugar-induced signal transduction in plants. Annual Review of Plant Physiology and Plant Molecular Biology, v. 51, p. 49-81, 2000.

STEPONKUS, P.L. et al. Effects of cold acclimation and freezing on structure and function of chloroplast thylakoids. Cryobiology, v. 14, p. 303-321, 1977.

SUZUKI, S. et al. The effects of nitrate on sprouting of grapevine buds and changes in amino acid concentration. Developments in Plant and Soil Sciences, v. 8, p. 863864, 1997.

WALTON, E.F.; CLARK, C.J.; BOLDINGH, H.L. Effect of hydrogen cyanamide on amino acid profiles in kiwifruit buds during budbreak. Plant Physiology, v. 97, p. 12561259, 1991.

WELLING, A.; PALVA, E.T. Molecular control of cold acclimation in trees. Physiologia Plantarum, v. 127, p. 167-181, 2006.

YOOYONGWECH, S. et al. Hydrogen cyanamide enhances MRI-measured water status in flower buds of peach (Prunus persica L.) during winter. Plant Omics Journal, v. 5, p. 400-404, 2012.

YOSHIOKA, H. et al. Seasonal changes of carbohydrates metabolism in apple trees. Scientia Horticulturae, v. 36, p. 219-227, 1988. 